\author{
Krzysztof Okoński \\ http://orcid.org/0000-0002-8779-2535 \\ Uniwersytet Kazimierza Wielkiego w Bydgoszczy \\ k.okonski@ukw.edu.pl \\ DOI: $10.35765 /$ pk.2020.3104.18
}

\title{
Drugorzędny drugi obieg. W trzydziestą rocznicę zniesienia cenzury w Polsce
}

\section{STRESZCZENIE}

Literatura podziemna istnieje obecnie tylko w archiwach historycznych lub w zbiorach prywatnych i nie ma szansy wpłynąć na współczesny dyskurs. Któż byłby dziś naprawdę zainteresowany prezentowanymi w niej liberalnymi poglądami, jej różnorodnością tematyczną i estetyczną, kiedy radykalne siły, fake newsy i trolle w coraz większym stopniu kształtują komunikację w przestrzeni publicznej? Czy eskalacja konfliktów ideologicznych w Polsce może prowadzić do instrumentalizacji mitu literatury i prasy dysydenckiej przez uczestników życia politycznego? Jaki potencjał dla badań literaturoi kulturoznawczych oraz dydaktyki tkwi w podziemnej literaturze i prasie? Czy digitalizacja druków drugoobiegowych ułatwia kultywowanie pamięci o tych publikacjach? I wreszcie - czy nadszedł czas demitologizacji niektórych aspektów kultury niezależnej?

30 lat po zniesieniu cenzury nadal aktualne jest pytanie o nieobecność w popularnych formach pamięci bohaterów polskiej historii - drukarzy, kolporterów i autorów.

SŁOWA KLUCZE: cenzura, PRL, komunizm, drugi obieg, pamięć kulturowa

\section{ABSTRACT}

Secondary Second Circulation. On the Thirtieth Anniversary of the Abolition of Censorship in Poland

Underground literature exists only in historical archives or in private collections - and stands no chance of affecting the contemporary debate. Who would be now really interested in liberal views or thematic and aesthetic diversity of underground literature when radical forces, fake news and trolls increasingly shape communication in the public space? Can the escalation of ideological conflicts in Poland lead to a more instrumental approach towards the myth of dissident literature and the press by political actors? What potential for literary and cultural research (but also for teaching) does the underground literature 
and press have? Does the transition from samizdat to digitization facilitate cultivating memory about these publications? And last but not least, is it time to demythologize some aspects of this culture?

30 years after the abolition of censorship, a question can still be asked why heroes of the Polish history such as printers, distributors and authors are not present in popular forms of remembrance.

KEYW ORD S : censorship, Polish People's Republic, communism, samizdat, cultural remembrance

Jakub Karpiński w wydanym w 1985 roku w Londynie i przedrukowanym trzy lata później przez podziemne wydawnictwo CDN słowniku Polskakomunizm - opozycja pod hasłem Literatura tak opisuje jej funkcjonowanie w okresie PRL: „Literatura polska po wojnie powstawała w Polsce i na emigracji, książki drukowano w Polsce i na emigracji oraz drukowano oficjalnie i nieoficjalnie. Te podziały się krzyżują” (Karpiński, 1988, s. 128). Marta Nadolna-Tłuczykont 28 lat później w swojej pracy o powrocie książek zakazanych podzieliła się refleksją, która nabiera szczególnego znaczenia w związku z erozją pamięci o przedstawionym przez Karpińskiego fenomenie twórczości poza cenzurą: „Książka traci współcześnie swe znaczenie i rangę, jaką miała w toku minionych wieków, gdyż mamy do niej łatwy dostęp; zakupić da się ją już wszędzie, w sklepie, kiosku, na stacji benzynowej, w supermarkecie, przede wszystkim jednak w Internecie" (Nadolna-Tłuczykont, 2013, s. 109). Badaczka odnosi się następnie do niewielkiego zainteresowania nieobecnymi w handlu lub wycofywanymi przed 1989 rokiem z bibliotek książkowymi prohibitami, które powstały jeszcze w dwudziestoleciu międzywojennym, po 1945 roku uznano je za niepożądane, natomiast po zmianie ustroju (mimo wznowień), rzadko pojawiały się w księgarniach. Na podstawie materiałów zebranych w Archiwum Państwowym w Katowicach autorka sporządziła katalog książek „zakazanych”. Obejmuje on publikacje autorów sprzed 1939 roku, a wśród pozycji objętych zakazem są nie tylko książki podejrzanych ideologicznie twórców albo publikacje o tematyce religijnej, legionowej, harcerskiej, antybolszewickiej, kresowej czy historycznej w czasach PRL zakwestionowano nawet niektóre powieści dla dziewcząt (m.in. z powodów obyczajowych - niedozwolony rodzaj romansu w Jawnogrzesznicy Ireny Zarzyckiej) lub książki zawierające elementy fantazji i baśniowości (Nadolna-Tłuczykont, 2013, s. 178).

Rok 1989 tworzy w dziejach kultury i literatury polskiej cezurę, wynikającą ze splotu wydarzeń, które m.in. ze względu na działalność drugiego obiegu i opozycji wykraczają poza zjawisko samoistnej „erozji systemu”. Mimo rocznicowych akcentów i dążenia do periodyzacji 
trudno w tym przypadku o wyznaczenie konkretnej daty, gdyż nawet rok 1989 stanowi jedynie symboliczną granicę. Fakt stosunkowo późnego zniesienia cenzury w Polsce (11 kwietnia 1990) nie oznaczał przecież w schyłkowym okresie istnienia PRL braku możliwości wydawania i zakupu materiałów objętych wcześniej nie tylko zakazem publikacji, ale także będących przedmiotem zainteresowania aparatu bezpieczeństwa. Mimo to ingerencje Urzędu Kontroli Publikacji i Widowisk (odtąd najczęściej zaznaczane w tekście cytatem z odpowiedniego punktu ustawy) nadal się zdarzały:

Kiedy jesienią 1989 r. Wacław Holewiński chciał wydać przedruk książki prof. Andrzeja Kamińskiego Koszmar niewolnictwa. Obozy koncentracyjne od 1886 roku do dzis. Analiza, urząd cenzorski nie wyraził zgody na publikację, ponieważ zawarte w niej opinie i sądy „w sposób oczywisty obrażają pozostające w sojuszu z Polską Państwo Radzieckie, godząc w konstytucyjną zasadę umacniania przyjaźni z ZSRR oraz w sojusz ze Związkiem Radzieckim”. W Hańbie domowej Jacka Trznadla warszawscy cenzorzy zakwestionowali 33 fragmenty; po złożeniu odwołania liczba ingerencji zmniejszyła się do 22. W styczniu 1990 r. z powieści Waldemara Łysiaka Dobry wypadły antysowieckie piosenki (Błażejowska, 2010, s. 248-249).

Jesienią 1989 roku bezdebitowa kultura kończyła swoją historyczną misję. We wrześniu tego samego roku Andrzej Kaczyński pisał w „Kulturze Niezależnej”, że niebezpieczeństwa grożące niezależności należy dostrzegać nie w przemocy policyjnej ani politycznej, lecz w ekonomicznej (Bertram, 2013, s. 238). Pół roku później, w maju 1990 roku, czyli miesiąc po zniesieniu cenzury w Polsce, w tym samym czasopiśmie ukazał się tekst pod wymownym tytułem Piękna byta przygoda. Zawiera on zwięzły i jednocześnie gorzki bilans okresu po historycznej decyzji Sejmu, zdejmującej z mediów kaganiec zapisów cenzuralnych:

Drugi obieg wszedł w szarą strefę. Już bezpieczny, ale niepewny przyszłości. Z dorobkiem nie do ogarnięcia (nawet na sposób bibliograficzny tylko) a już opluwany, zdezawuowany, nie przez wrogów, bo to znosił mężnie, lecz przez swojaków, więc tym boleśniej. Zepchnięty na margines, między pokątnych wydawców pornografii, fantastyki, kryminałów (Bober, 1990, s. 105).

Justyna Błażejowska, autorka wydanej w 2010 roku książki Papierowa rewolucja. $Z$ dziejów drugiego obiegu wydawniczego w Polsce 19761989/1990, opisując ten okres, kreśli wręcz apokaliptyczny obraz zmierzchu drugiego obiegu: „Nowe-stare władze weszły w swą rolę szybko i dobrze. Ulegając rygorystycznemu i ślepemu fiskalizmowi wicepremiera Leszka Balcerowicza, traktowały niepoddające się kontroli inicjatywy jako 
curiosa, które nie podlegają ochronie, a przeciwnie - mają jak najszybciej zniknące” (Błażejowska, 2010, s. 249).

W warunkach hiperinflacji jesienią 1989 roku i wczesnej fazy transformacji gospodarczej, której towarzyszył gwałtowny wzrost bezrobocia, zakup książek i rozwój czytelnictwa stały się w Polsce sprawą drugorzędną. Mimo to właśnie w tym wysoce niekorzystnym dla literatury czasie ukazały się książki, które przed 1989 rokiem nie miały szans na legalną publikację i niezależnie od zmiany ustroju nadal cieszyły się zainteresowaniem czytelników - choćby ze względu na chęć nadrobienia wymuszonych cenzurą zaległości lekturowych. Należy jednak w tym miejscu zaznaczyć, że owo zainteresowanie obejmowało głównie wznowienia dawnych prohibitów. W odróżnieniu od powielanych zazwyczaj na marnym papierze, zapełnionych drobnym drukiem, bywało, że wręcz miejscami nieczytelnych książek z drugiego obiegu, nowe, legalne wydania gwarantowały nie tylko dostęp do zakazanych niedawno treści, ale przede wszystkim zdecydowanie większą trwałość i komfort lektury dla czytelnika. Periodyki, ulotki i całe tomy literatury pięknej, które drukowano kilkanaście miesięcy wcześniej ze świadomością rewizji i konfiskaty, stały się nagle - podobnie, jak sprzęt drukarski - jedynym majątkiem podziemnych drukarni, który zresztą trudno było zamienić na tracącą i tak na wartości gotówkę.

Wkrótce okazało się, że zerwały się więzi łączące szefów wydawnictw, drukarzy i kolporterów - najczęściej anonimowych „żołnierzy”. Adam Mielczarek zauważa wprawdzie w swojej książce, że o ile dla byłych współpracowników wydawnictw podziemnych charakterystyczna była „silna ideologiczna afirmacja rezultatów rewolucji roku 1989” (Mielczarek, 2006, s. 38), to w sensie materialnym skorzystali oni z transformacji ustrojowej o wiele rzadziej niż ich dawni prześladowcy. Odrębność losów elity podziemnego ruchu i jego szeregowych działaczy stała się widoczna, gdy członkom kierownictwa wiodących oficyn zaoferowano stanowiska $\mathrm{w}$ instytucjach państwowych lub dokonali oni (cytując tytuł rozdziału w książce Śpiacy rycerze Adama Mielczarka) „desantu do administracji państwowej” (Mielczarek, 2006, s. 63-80).

Naturalna w 1990 roku - i pożądana - kolej rzeczy, jaką było zniesienie cenzury i monopolu informacyjnego oraz koniec działalności wydawnictw bezdebitowych pozwalają spojrzeć na wydarzenia sprzed trzydziestu lat nie tylko z powodów rocznicowych. Zasięg i różnorodny dorobek polskiego drugiego obiegu należą do przeszłości, jednak dystans czasowy, dynamika współczesnego życia politycznego oraz obserwacja współczesnych kierunków, w których rozwija się kultura pamięci, skłaniają do zadania następujących pytań:

- Jakie wyzwania dydaktyczne wiążą się z kultywowaniem pamięci o drugim obiegu? 
- Czy digitalizacja publikacji bezdebitowych jest szansą na upowszechnienie ich treści?

- Czy polaryzacja dyskursu publicznego w Polsce przyczynia się także do zawłaszczenia etosu drugiego obiegu przez uczestników bieżących sporów?

- Perspektywa 30 lat od zniesienia cenzury pozwala spojrzeć na kulturę podziemną w sposób kompleksowy i pozbawiony doraźnego kontekstu politycznego. Czy jej twórcom udało się wypracować wartości, które są nadal aktualne?

- Do jakiego stopnia mechanizmy „wewnętrznej ewaluacji” drugiego obiegu mogą być obecnie punktem wyjścia dla prób weryfikacji narodowych mitów?

Niniejszy artykuł nie wyczerpuje oczywiście całego spektrum zagadnień, które warto omówić z perspektywy trzydziestu lat. Niezależnie od istniejących w obiegu naukowym opracowań na temat historii drugiego obiegu, mogą one być jedynie przyczynkiem do refleksji nad dzisiejszymi przejawami pamięci o tej formie protestu. Sporym wyzwaniem jest już zresztą próba ilościowego ujęcia podziemnego ruchu wydawniczego. Profesor Andrzej Paczkowski w swoich ostrożnych ocenach zakłada, że odbiorcami drugiego obiegu były głównie osoby z wykształceniem wyższym, mieszkańcy dużych miast, rzadziej robotnicy (Błażejowska, 2010, s. 261). Adam Mielczarek uważa, że bezdebity czytało 26 proc. populacji od 15. roku życia, czyli ok. 3,5 miliona obywateli PRL. Według Konstantego Geberta ta liczba wynosi z kolei 1,5 do 2 milionów osób. Konkretne dane wydawnicze (choć nie w każdym przypadku) zdecydowanie łatwiej zebrać, analizując wielkość produkcji poza cenzurą. Justyna Błażejowska wskazuje m.in. na rejestr Biblioteki Narodowej, obejmujący imponującą liczbę 6500 publikacji (wspomnieć tu należy także o obszernych kolekcjach bezdebitów w posiadaniu Biblioteki Jagiellońskiej, KUL, UWr czy UMP). Warszawska KARTA wykazuje w swoim spisie 3083 czasopisma. Ich nakłady były bardzo zróżnicowane - od kilkuset do blisko 50000 egzemplarzy (,Tygodnik Mazowsze”) (Błażejowska, 2010, s. 259-260). Pomijając całkiem zrozumiałe (w kontekście konspiracyjnej specyfiki) powody powyższych rozbieżności, można z pewnością uznać, że polski drugi obieg stanowił w porównaniu z podobnymi inicjatywami w NRD, Czechosłowacji, ZSRR czy na Węgrzech wyjątkowe zjawisko i to zarówno w wymiarze ilościowym, jak i jakościowym (Gasztold-Seń, Jarska i Olaszek, 2016).

Trzydzieści lat po samoistnej likwidacji tego ruchu można nawiązać do postawionego wcześniej pytania o aktualny potencjał podziemnego dorobku wydawniczego i jego dziejów. W Polsce brakuje równie spektakularnego symbolu przemian demokratycznych, jakim w NRD był upadek 
muru berlińskiego. Polskim ambicjom międzynarodowego „przelicytowania“ symboliki muru berlińskiego (o ile takowe istnieją), mogłoby sprostać dziedzictwo „Solidarności”, które jednak wypaliło się w sporach jej dawnych liderów. Taką rolę mógłby odegrać właśnie drugi obieg - fenomen kulturalny, który niegdyś stanowił punkt odniesienia i inspirację dla ruchów demokratycznych w całym bloku wschodnim. Stanowił on wyspę wolności, którą stworzyli pisarze, publicyści, drukarze, kolporterzy i czytelnicy. Niewiele wynika z demonstrowania różnych fantomowych bólów historycznych (o aberracjach w stylu Wielkiej Lechii nie wspominając), jeżeli wyjątkowość polskiego drugiego obiegu pozostaje faktem istniejącym głównie w artykułach i książkach naukowych. Mimo wspomnianego wyżej rozpoznawalnego symbolu w postaci upadku muru berlińskiego pamięć o pokojowej rewolucji w Niemczech Wschodnich i tamtejszym samizdacie/tamizdacie (książki drukowane na Zachodzie i przemycane do NRD np. w innych okładkach) również u zachodniego sąsiada nie ma raczej na co dzień „koniunktury”. Cieszyć zatem powinno, że Gerhard Gnauck już w 1999 roku przypomniał Niemcom postać i dorobek Mirosława Chojeckiego, nazywając go największym wydawcą podziemnym w bloku wschodnim (Gnauck, 1999).

Drukarze, wydawcy, kolporterzy i autorzy byli niewątpliwie bohaterami podziemnego życia kulturalnego, ponieważ w imię wolności słowa narażali siebie na różnorodne represje: aresztowanie, konfiskatę mienia, książek, maszyn i oszczerstwa pod ich adresem w państwowych mediach. 30 lat po zniesieniu cenzury trudno znaleźć odpowiedź na pytanie, dlaczego pamięć o ich dokonaniach (i co najważniejsze - historycznym zwycięstwie) nie jest obecna w jakże powszechnym ostatnio zainteresowaniu Polaków wznoszeniem (choćby na facebookowych profilach) prywatnych panteonów ku czci powstańców warszawskich, bohaterów wojny polsko-bolszewickiej, żołnierzy wyklętych albo husarii. Adam Mielczarek w cytowanej wcześniej książce o losach działaczy drugiego obiegu po 1989 roku pisze:

Po części nie można się temu dziwić: nie ma książek, filmów, opracowań, które mogłyby takich bohaterów w świadomości społecznej wylansować czy nawet po prostu ujawnić, że dane osoby w podziemiu były i że coś ważnego w nim robiły. Historia nie pisze się sama - gdy nie ma dostępnych w języku powszechnej komunikacji symboli i mitów - społeczna pamięć umiera lub przywdziewa powoli cudze szaty (Mielczarek, 2006, s. 133).

Być może odpowiedzi należy szukać także w kwitnącym obecnie zainteresowaniu militariami, rekonstrukcjami wojennymi czy postulatami 
szerszego dostępu do broni, którego zwolennicy za naturalne wzorce obierają weteranów walki zbrojnej, a nie autorów esejów literackich. Z drugiej strony kryzys czytelnictwa i zmieniony po 1989 habitus pisarzy, także zaangażowanych niegdyś w obronę wolności słowa i literatury, stają się przyczyną marginalizacji twórców - niezależnie od uprawianych przez niektórych z nich gier marketingowych, autokreacji medialnych i generalnie porzucenia przez nich (mają do tego prawo) „odrobiny powagi i płaszcza Konrada”, których jeszcze w 1995 roku oczekiwał od kolegów po piórze Artur Międzyrzecki (1995, s. 13).

Mając na uwadze antykomunistyczny, katolicko-narodowy, martyrologiczny i mesjanistyczny wydźwięk wielu publikacji bezdebitowych (zwłaszcza w stanie wojennym), można uznać, że znakomicie nadają się one do swego rodzaju ideowej implementacji na współczesnym, jakże podatnym na taką narrację, gruncie. Stefan Chwin przywołuje kilka przykładów tego rodzaju uniesień:

Pragnienie wysokiej romantycznej „dykcji” zdarzeń było powszechne także w politycznym folklorze lat 1981-1983. [...] W teatrze i poezji odżyły wyobrażenia mesjanistyczne (Anhelli zespołu NST, powieść Henryka Wańka Dziady berlinskie, Brylla Adwent). Pisząc o 13 grudnia 1981 roku, Rymkiewicz przywoływał topos Polski umierającej na krzyżu, a Bryll nawiązywał do tradycji powstania 1831 roku (Chwin, 1994, s. 22).

Niezależnie od nieuprawnionego sięgania do cudzych zasług w celu legitymizacji własnej działalności politycznej ${ }^{1}$ byłaby to próba budowania nieprawdziwej, bo monolitycznej legendy polskiej kultury protestu w PRL. Sprzeciw może również budzić zawłaszczanie konwencji drugiego obiegu we współczesnych kontekstach medialnych i ideowych, zwłaszcza jako formy budowania opozycji obywatel - (opresyjne) państwo i tym samym kwestionowania demokratycznej legitymacji III RP. Doskonale w tej konwencji odnajduje się pieśniarz i publicysta Paweł Piekarczyk, którego płyta Drugi obieg w kondominium (2012) zawiera treści: „Teksty te komentują między innymi sytuację w naszym kraju, ograniczanie wolności - również $\mathrm{w}$ internecie, o kłamstwie otumaniającym ludzi. W dużej mierze poświęcone też jest polityce historycznej śp. Lecha Kaczyńskiego" (Pawet Piekarczyk...). Bez najmniejszych oporów do tradycji drugiego obiegu sięga Joanna Lichocka, której słowa umieszczono w tytule tekstu na portalu wPolityce: „Po Smoleńsku powstał drugi obieg medialny. «Dwie różne Polski, dwa obiegi, dwa kanały kolportażu»" (SIL,

1 Por. „Działamy jak Armia Krajowa” - Paweł Kukiz cytowany na okładce „Do Rzeczy”; Okładka 2015. 
2011). Czy w zestawieniu z zasięgiem cenzury i skalą represji wobec podziemia w PRL powyższe cytaty, które bez trudu można znaleźć w ogólnodostępnej sieci i w gazecie kupionej w kiosku, nie są relatywizowaniem komunistycznej cenzury i monopolu informacyjnego?

Być może na tle przytoczonych tutaj górnolotnych haseł wydawnicze osiagnięcia podziemnych oficyn w PRL nie przedstawiają już sobą większej wartości. To oczywiście stwierdzenie podszyte ironią. Paweł Śpiewak pisze w swojej książce Pamięć po komunizmie, że od 1976 roku w drugim obiegu dzięki licznym bezdebitowym przedrukom literatury i artykułów prasowych zza żelaznej kurtyny udało się częściowo zredukować dystans, jaki dzielił polską myśl od zachodniej, natomiast upadek komunizmu pozwolił dokończyć ten proces (Śpiewak, 2005, s. 12). Podziemnej scenie literackiej można zawdzięczać nie tylko liczne próby przybliżenia czytelnikowi polskiemu twórczości Czesława Miłosza, Józefa Mackiewicza czy Gustawa Herlinga-Grudzińskiego. Jan Olaszek w rozdziale Podziemne bestsellery dokonuje zwięzłej analizy profilu tematycznego wydawanych w podziemiu książek autorów zagranicznych, ich rangi literackiej, zainteresowania drugiego obiegu literaturą różnych krajów (ze szczególnym miejscem literatury krajów b. ZSRR i Czechosłowacji), wymieniając nazwiska kluczowe dla kultury europejskiej (niekoniecznie ze względu na polityczne zaangażowanie), takie jak George Orwell, Max Weber, Josif Brodski, Milan Kundera czy Günter Grass (Olaszek, 2015, s. 292-293).

O ile obecność tych (i wielu innych) autorów w wydaniach bezdebitowych została już ujęta w leksykalne ramy (Czachowska i Dorosz, 1991; Kandziora i Szymańska, 1999) i stała się przedmiotem badań literaturoznawczych, to mając na uwadze Humboldtowską jedność badań i nauczania, należałoby zapytać o miejsce drugiego obiegu we współczesnej dydaktyce. Justyna Błażejowska pisze we wspomnianej we wstępie książce, że do „[...] wawrzynu chwały (drugiego obiegu - K.O.) dodać trzeba listek edukacyjny. Przemysław Czapliński zauważał: «na książkach zakazanych kształciły się wszystkie roczniki studiów humanistycznych lat 1980-1989»” (Błażejowska, 2010, s. 287). Dzisiejszy stan wiedzy w tym zakresie Błażejowska ilustruje następującymi przykładami:

Prof. Ryszard Terlecki z zażenowaniem mówił o jednym ze studentów egzaminowanych z historii najnowszej: „na pytanie: «Co to jest drugi obieg?» odpowiedział, że to są książki drugi raz sprzedawane, czyli książki na rynku antykwarycznym. Nie jest to wypadek odosobniony, czego dowodzą wypowiedzi absolwentów studiów podyplomowych Instytutu Historycznego Uniwersytetu Warszawskiego. Ich wiedza o wydawnictwach niezależnych sprowadzała się do przekonania, iż są to «różnorodne materiały wydawane w tzw. 'podziemiach'» albo «prasa podziemna, 
wydawana przez patriotów». O tym, w jakim oceanie niewiedzy i ignorancji na co dzień się poruszamy, świadczy przykład studentki polonistyki: brzydki papier oraz niewyraźny druk drugoobiegowego tomiku Czesława Miłosza to dla niej... świetny chwyt marketingowy” (Błażejowska, 2010, s. 257-258).

Mimo niezbyt reprezentatywnego wyboru cytatów o drugim obiegu każdy czytelnik niniejszego tekstu, który oprócz badań literaturoznawczych zajmuje się dydaktyką, może wyrobić sobie zdanie na podstawie swoich doświadczeń zawodowych. Podejmując próbę bardziej systemowego spojrzenia na przyczyny niewielkiej wiedzy o drugim obiegu, warto zapoznać się ze staraniami, które w tej mierze podejmuje polskie szkolnictwo. Otóż tematyka kultury niezależnej (zwykle określana jako literatura stanu wojennego) była obecna w planach nauczania niejednej polskiej szkoły głównie na papierze - najczęściej ze względu na brak czasu w trzeciej (do ubiegłego roku ostatniej) klasie liceum. Problem jednak zaczyna się na wcześniejszych etapach edukacji. Podręcznik do historii dla 4. klasy szkoły podstawowej pt. Wczoraj $i d z i s$, opracowany na podstawie programu nauczania historii w klasach 4-8 szkoły podstawowej autorstwa Tomasza Maćkowskiego, zawiera lekcję Solidarnośc $i$ jej bohaterowie, gdzie o prasie i literaturze podziemnej nie znajdziemy ani słowa. Jeżeli (przy całym szacunku dla ich heroizmu) na temat Pilecki i Inka - zotnierze nieztomni przeznaczono osobną lekcję, to trudno uniknąć pytania o powód zaznaczenia na czerwono lekcji o Bitwie Warszawskiej 1920 roku jako zagadnienia dodatkowego (Olszewska, Surdyk-Fertsch, i Wojciechowski, 2020, s. 118-121, 132-135, 142).

Trudno nie zgodzić się z argumentem, że ograniczony czas przeznaczony na - mówiąc nauczycielskim żargonem - przerobienie materiału, musi zakładać pewną selektywność i możliwości percepcyjne ucznia. Jeżeli jednak 11-latek jest z różnych, zapewne uzasadnionych, powodów pozbawiony symbolicznej choćby wiedzy o podziemnym ruchu wydawniczym w PRL (w którym ukazywały się nawet czasopisma i książki dla dzieci), a potrafi przeanalizować pontyfikat Jana Pawła II (również osobna lekcja), to kolejna próba znalezienia odpowiedzi na pytanie o polską kulturę protestu lat 70. i 80. powinna nas kierować do 3. klasy liceum, a zatem do ucznia stojącego u progu egzaminu dojrzałości. Otóż podręcznik dla klasy 3. liceum i technikum pt. Przesztość to dziś (wyd. wieloletnie z 2015 roku), autorstwa Jacka Kopcińskiego, w rozdziale 6 Duch oporu $i$ zmiany zawiera m.in. następujące zagadnienia: Poza cenzurą - Drugi obieg wydawniczy - Poezja stanu wojennego - Stanisław Barańczak, Spójrzmy prawdzie w oczy, Wypetnić czytelnym pismem, Garden party i (przeznaczony do omówienia w programie rozszerzonym) wiersz Jana Polkowskiego Tak, jestem 
obcy (Kopciński, 2015). Plan wynikowy zakłada z kolei, że uczeń (w przypadku wymagań na poziomie podstawowym) po 5 godzinach zajęć m.in.:

- wie, że w życiu politycznym i kulturalnym PRL-u istniał nurt „świadectwa i sprzeciwu” sygnowany miesiącami politycznych przełomów; wymienia niektórych twórców mieszczących się w tym nurcie i ważne dzieła [...]

- wie, czym był tzw. drugi obieg wydawniczy [...]

- wyjaśnia określenie „poezja stanu wojennego” (Kosyra-Cieślak, 2015).

Lektura treści w podręczniku i w planie wynikowym utwierdza w przekonaniu, że uczeń i nauczyciel otrzymują materiał, który jest niełatwą próbą syntetycznego ujęcia problemu (także z uwzględnieniem różnic w poglądach politycznych, estetycznych oraz biografii omawianych autorów). Ze względu na ograniczenia czasowe ze zrozumieniem można też przyjąć decyzję o włączeniu do programu krótkiej formy (wierszy) autorstwa dwóch wybitnych i jednocześnie reprezentatywnych dla tej sceny poetów. Z drugiej strony we wspomnianych materiałach dydaktycznych łatwo zauważyć znaczący udział zagadnień teoretycznoliterackich, niezbędnych w analizie ich poezji, zanurzonej nie tylko w ówczesnej rzeczywistości i języku (zwłaszcza u Barańczaka), jakże odległych od doświadczeń pokoleniowych i wiedzy dzisiejszych licealistów. Jeżeli założyć, że przybliżenie specyfiki tamtego okresu poprzez literaturę jest celem nadrzędnym wobec teoretycznoliterackiej analizy związków formalnych, to zasadne wydaje się pytanie o możliwość włączenia, a może wręcz zastąpienia wymienionych utworów fragmentami tekstów programowych drugiego obiegu. Cenną propozycją lekturową byłby na przykład artykuł Stanisława Barańczaka, otwierający pierwszy numer „Zapisu” z 1977 roku, w którym wyjaśnia on podwójne znaczenie tytułu czasopisma (zapis wydarzeń i zapis cenzorski, obejmujący określone utwory i ich autorów) oraz przedstawia uwarunkowania literatury w czasach komunizmu. Innym pomysłem byłoby omówienie na zajęciach fragmentów wywiadów, wstępów autorskich do polskich wydań czy przedruków z samizdatu wschodnioeuropejskiego na temat drugiego obiegu w PRL. Pamiętając o ważnych inicjatywach wydawniczych, dzięki którym polski czytelnik mógł w całości poznać cenzurowane lub zakazane utwory takich autorów, jak Reiner Kunze, Jürgen Fuchs czy Günter Grass (ze względów zawodowych skupię się na literaturze niemieckiej), trudno pominąć ich wypowiedzi (oraz informacje w prasie zachodnioniemieckiej) o znaczeniu polskiego ruchu wydawniczego poza cenzurą.

Historia kultury niezależnej w PRL oraz jej międzynarodowych kontekstów jest dobrze udokumentowana i zbadana, czego dowodem są publikacje historyków, politologów, prasoznawców, polonistów i badaczy reprezentujących filologie obce. Mimo zgłoszonych powyżej uwag do 
wybranych treści i zaplanowanych efektów nauczania można uznać, że polska szkoła już od 1990 roku (wydanie przez Ossolineum tomu Bożeny Chrząstowskiej Literatura wspótczesna źle obecna w szkole. Antologia tekstów literackich $i$ pomocniczych dla klas maturalnych) jest wyposażona w podręczniki umożliwiające zdobycie takiej wiedzy.

Elżbieta Misiakiewicz pisząc w 2007 roku o problemach związanych z nauczaniem literatury drugiej emigracji, zwracała uwagę w swoim artykule (podkreślając w tytule własne doświadczenie praktyczne) na pobieżne traktowanie tego tematu z powodu specyfiki pracy w ostatnim roku nauki szkolnej (Misiakiewicz, 2007, s. 18). Powyższe stwierdzenie można odnieść również do zagadnień związanych z drugim obiegiem (zwłaszcza że autorka nawiązując do podręcznika Przesztość to dziś, wymienia także drugi obieg i cenzurę). Konkluzję artykułu poprzedzają tytuły książek wydanych po 1990 z przeznaczeniem do nauczania w szkole średniej, w różnych ujęciach przybliżających uczniom m.in. literaturę bezdebitową. Po ukazaniu się serii takich wydawnictw we wczesnych latach 90 . nastąpił proces, o którym Misiakiewicz pisze:

[...] emocje opadły, nastał czas, kiedy literatura emigracyjna przestała być owocem zakazanym. Dwie wskazane przeze mnie skrajne postawy (pomijanie tej literatury i nadmierne jej eksponowanie) zostały poddane rygorom rzeczywistości szkolnej i zweryfikowane przez wymogi reformy oświaty, zmianę optyki nauczania, przewartościowania priorytetów edukacji. Odnalezienie złotego środka wymogła sama obszerność materiału rzeczowego, której szkolna dydaktyka nie jest w stanie podołać bez rozsądnej selekcji (Misiakiewicz, 2007, s. 24).

Mając na uwadze treść podręczników i antologii szkolnych, pasje nauczycieli, sukces wystawy w Europejskim Centrum Solidarności w Gdańsku o bibule w PRL, działalność Ośrodka KARTA, IPN, Stowarzyszenia Wolnego Słowa, organizację Tygodnia Książek Zakazanych czy obchody Roku Kultury Niezależnej (2009) można uznać, że zarówno instytucjonalne formy pamięci o komunizmie, badania naukowe, jak i szkolnictwo tworzą idealny wręcz konglomerat, służący upowszechnianiu tej wiedzy wśród młodych Polaków. Przytoczone we wstępie niniejszego artykułu wypowiedzi znanych naukowców i wykładowców akademickich o nieznajomości tej tematyki wśród studentów czołowych uczelni oraz nieobecność drugiego obiegu w popularnej kulturze memorialnej zakłócają jednak tę optymistyczną wizję.

Pewnym wyjściem z tej sytuacji wydaje się digitalizacja wydawnictw podziemnych, stanowiąca próbę połączenia specyficznej podziemnej kultury słowa drukowanego z nowoczesną technologią i współczesnymi 
formami odbioru literatury. Działające archiwa sieciowe i profile społecznościowe, które mają za zadanie popularyzację dorobku drugiego obiegu, stanowią jednak tematyczną niszę $\mathrm{w}$ porównaniu $\mathrm{z}$ równie popularnymi, co powierzchownymi kanałami wideo i fanpage'ami na Facebooku o historii komunizmu. Problemu digitalizacji i powszechnego dostępu online do drugoobiegowych cymeliów nie rozwiązują pojedyncze inicjatywy (np. wywodzącego się z podziemia i działającego nadal „Czasu Kultury”), w ramach których powstaje cyfrowa kopia wydawnictwa bezdebitowego. Bardzo udanymi próbami kompleksowego zmierzenia się z tym wyzwaniem (m.in. wobec rozproszenia wspomnianych wcześniej indywidualnych projektów digitalizacyjnych) było powołanie centralnego zbioru przetworzonych cyfrowo druków podziemnych - w Niemczech portalu www.ddr-samisdat.de, a w Polsce Wirtualnej Czytelni Bibuły (http://repozytorium.encysol.pl/wiki/WCB_Katalog_alfabetyczny). Odnosząc się do zgłoszonych wcześniej postulatów, jako przykład dydaktyzacji treści związanych z kulturą protestu można podać portal www.jugendopposition.de, dotyczący opozycji młodzieżowej w NRD i oferujący oprócz digitalizatów bibuły, zdjęć i nagrań audio/wideo, także wskazówki dla nauczycieli oraz gotowe arkusze z zadaniami dla uczniów. W obu krajach zrealizowano także dwa projekty „analogowe”, dzięki którym zakazane niegdyś książki ponownie (lub w przypadku autorów z NRD po raz pierwszy) ukazały się drukiem. W Niemczech taką inicjatywą była seria Przemilczana Biblioteka (Verschwiegene Bibliothek) pod redakcją Ines Geipel i Joachima Walthera, dzięki której udostępniono twórczość represjonowanych autorów z niemal całego okresu istnienia NRD. Odpowiednikiem tej serii w Polsce był Kanon Literatury Podziemnej, o którym Tomasz Burek napisał:

Wysokonakładowe reedycje książek jeszcze ćwierć wieku temu oficjalnie zakazanych to niepowtarzalna okazja, żeby utrwalić w świadomości współczesnych Polaków obraz „drugiego obiegu” jako wspólnoty mieniącej się odcieniami, wspólnoty poszukiwań i sporów, umysłowo swobodnej i estetycznie zróżnicowanej².

Pisząc kilka lat temu o polskich i niemieckich próbach przywrócenia do zbiorowej pamięci dorobku drugiego obiegu w postaci tradycyjnej i cyfrowej, opatrzyłem swoje obserwacje tytułem Czy istnieje życie po śmierci? Pierwotnie odnosił się on do samolikwidacji kultury podziemnej po 1990 roku, ale w szerszym kontekście do nikłych szans jej symbolicznej resuscytacji ćwierć wieku po upadku komunizmu, również w kontekście dostępniejszej i darmowej (choć obejmującej raczej czasopisma niż książki) oferty

2 T. Burek, tekst na okładce Stanu po zapaści Jacka Bocheńskiego (2009). 
cyfrowej. Rzeczywistość bardzo szybko zweryfikowała te wnioski - znakomity portal www.ddr-samisdat.de, zawierający także teksty z NRD-owskiego samizdatu o Polsce, został usunięty z sieci z powodu zmian własnościowych, a Wirtualna Czytelnia Bibuły od listopada 2017 roku (wtedy po raz pierwszy odnotowałem zakłócenia w funkcjonowaniu tego portalu) boryka się z problemami z prezentacją własnych zasobów: długa lista czasopism wprawdzie zachęca do lektury, ale mimo upływu czasu od wspomnianej daty można oglądać jedynie pojedyncze, dobrane przypadkowo strony. Pozostają zatem w ramach wspomnianego kanonu wznowienia książek oferowanych promocyjnie za złotówkę w jednej z toruńskich księgarń.

Chcąc przywrócić pamięć o drugim obiegu, można sięgnąć do wypowiedzi Henryka Grynberga dla drugoobiegowego „Czasu Kultury”. Zapytany wówczas (w 1987 roku) o rolę wydawnictw niezależnych w Polsce, stwierdził:

Jest to zjawisko niezmiernie ważne. Mnie się zdaje, że po latach, jeśli sytuacja pozostanie taka, jaka jest, to cała historia literatury polskiej będzie odczytywana na podstawie wydawnictw podziemnych, a nie na podstawie oficjalnego obiegu, który jest na bardzo niskim poziomie" (Rozmowa..., 1987, s. 110).

Jan Olaszek pisząc 28 lat później o podziemnym ruchu wydawniczym, wskazuje natomiast na zróżnicowanie podziemnej sceny literackiej nie tylko ze względu na programowy wręcz pluralizm tematyczny, ideowy i formalny. Kultura niezależna oznaczała wszak wolność od cenzury, ale nie zawsze od grafomanii. Olaszek przywołuje w kontekście wewnętrznych, drugoobiegowych rozrachunków m.in. powieść Tadeusza Konwickiego Podziemna rzeka, podziemne ptaki z 1984 roku, traktującej o ukrywającym się - i ignorowanym przez SB - opozycjoniście, ratującym dla potomności matryce z poezją niskich lotów (Olaszek, 2015, s. 296).

O ile wydawanie sądów o podziemnej literaturze jest z dzisiejszej perspektywy dość komfortowym zajęciem, ponieważ opiera się wyłącznie na kryteriach artystycznych, to „wewnętrznej ewaluacji”, którą praktykowali drugoobiegowi publicyści, recenzując książki wydane poza cenzurą, mogła przecież towarzyszyć myśl, że propaganda wykorzysta spory literackie do skłócenia środowisk opozycyjnych. Krytycznych uwag nie szczędzono mimo to nawet laureatowi Nagrody Kulturalnej „Solidarności” Jackowi Bocheńskiemu: „Takim nadużyciem jest właśnie Stan po zapaści Jacka Bocheńskiego. Tytuł tej książki oddaje nie tyle duchowy stan kraju (jak sobie tego życzył autor), ile ilustruje dobrze obecną sytuację niezależnej kultury" (Frąckowiak, 1989, s. 213). Leszek Szaruga opisał ten stan (zresztą nie tylko w artykule: Szaruga, 1986b, s. 141) w uniwersalnym 
kontekście: „Uczucia nieokiełznane przez ironię, autoironię-mogą się źle przysłużyć polskiej kulturze. Myślę o martyrologicznym patosie, o tonacji kombatanctwa, o nowym mesjanizmie, które są widoczne w coraz bardziej sentymentalno-wzniosłej aurze naszej literatury” (Szaruga, 1986a, s. 32). Rafał Grupiński polemizując w „Czasie Kultury” ze wzmiankowanym tekstem Szarugi, który ukazał się w numerze paryskiej „Kultury” z maja 1986 roku, charakteryzuje go następująco:

[...] ciekawy szkic Leszka Szarugi Wielkie oczekiwanie poświęcony kulturze niezależnej w Polsce, jej obecnym przemianom, jej uzależnieniem zewnętrznym i wewnętrznym oraz jej najbliższej przyszłości.

W dalszej części Grupiński formułuje osąd ciekawy także w kontekście dzisiejszych sympatii politycznych postaci wymienionych w poniższym cytacie (włączając samego Grupińskiego):

Nadmierne zaangażowanie po jednej stronie sporu przynosi szkody literaturze, mówi Leszek Szaruga. Czy aby tak jest naprawdę? Może zaszkodzić, no cóż, każdemu mało utalentowanemu artyście, podobnie jak każdy inny temat, może także obniżyć loty tego, kto porzuca wypracowany przez siebie warsztat i sięga w nieznane, kierując się emocjami, tak jak stało się w wypadku ostatnich powieści Tadeusza Konwickiego. Może jednakże przynieść efekty zaskakująco ciekawe, tak jak w wypadku najlepszej książki politycznej ostatnich lat, a mianowicie Rozmów polskich latem 1983 Jarosława Marka Rymkiewicza (Grupiński, 1987, s. 43).

Współczesny dyskurs publiczny, jakże często naznaczony postępującą radykalizacją i polaryzacją, wydaje się żywym zaprzeczeniem form i treści wypracowanych w drugoobiegowych polemikach - nie tylko z powodu medialnej dominacji twitterowego komunikatu nad wyrafinowanym esejem literackim. Upływ lat od początku transformacji ustrojowej w Polsce nie zmienia ponadto faktu, że pytania o polityczną instrumentalizację literatury, zasadność podziału na kulturę świecką i katolicką, polski mesjanizm i rozumienie wolności, zadawane niegdyś przez Marcina Króla, Aleksandra Wirpszę („Leszka Szarugę”) czy Rafała Grupińskiego są nadal aktualne. Wiedza o drugim obiegu to także znajomość przemian ideowych osób, które go tworzyły. Zmienność polskich losów ilustrują zarówno życiorysy postaci afirmujących niegdyś system komunistyczny i tworzących później drugi obieg, wśród nich m.in. Macieja Łopińskiego, Krzysztofa Czabańskiego, Józefa Kuśmierka, Iwony Śledzińskiej-Katarasińskiej, jak i dawnych bohaterów podziemnej sceny, toczących z sobą od ponad ćwierćwiecza zażarty spór o teraźniejszość i przeszłość (np. Adam Michnik i Antoni Macierewicz). 
Jacek Trznadel pisze we wstępie do tomu rozmów z pisarzami uwikłanymi w socrealizm i stalinizm:

Cóż więc mówi tytuł tej książki, odnoszący się do dziejów społeczeństwa polskiego po wojnie? Że mianowicie w latach powojennych dokonywało się to, co nazwałem za Norwidem hańbą domową, to jest hańbą w Polsce przez Polaków spowodowaną (Trznadel, 1990, s. 9).

Powyższa diagnoza, szczegółowo omówiona na kartach książki, nie zmniejsza w żadnym razie udziału zewnętrznego czynnika w ksztaltowaniu rzeczywistości PRL, natomiast nawiązuje do wspomnianego wcześniej szlachetnego obowiązku krytycznego rozrachunku z własnym środowiskiem i narodem. W trzydziestolecie zniesienia cenzury w Polsce i w rocznicę samolikwidacji drugiego obiegu wiedza o dylematach moralnych i artystycznych autorów z tego kręgu, o ogromnej ofiarności i wysiłku organizacyjnym drukarzy, wydawców i kolporterów czy wreszcie o samych książkach i czasopismach nie może zostać wyparta przez narrację typową bardziej dla patriotycznej czytanki niż dla dojrzałej kultury pamięci.

\section{Bibliografia}

Bertram, Ł. (red.). (2013). Obieg NOW-ej. Warszawa: Ośrodek KARTA i Instytut Pamięci Narodowej.

Błażejowska, J. (2010). Papierowa rewolucja. Z dziejów drugiego obiegu wydawniczego w Polsce 1976-1989/1990. Warszawa: Instytut Pamięci Narodowej.

Bober, L. [wł. Kaczyński Andrzej]. (1990). Wydarzenia. Piękna była przygoda. Kultura Niezależna, 61, 101-106.

Bocheński, J. (2009). Stan po zapaści. Warszawa: Oficyna Wydawnicza Volumen i Bellona.

Chwin, S. (1994). Dlaczego upadek komunizmu zaskoczył literaturę polską? Teksty Drugie, 1, 5-28.

Czachowska, J. i Dorosz, B. (1991). Literatura i krytyka poza cenzura 19771989. Wrocław: Wydawnictwo „Wiedza o Kulturze”.

Frąckowiak, S. (1989). Getto niezależnej kultury. Czas Kultury, 9-10, 210-213.

Gasztold-Seń, P., Jarska, N. i Olaszek J. (red.). (2016). Drugi obieg $w$ PRL na tle samizdatu w panstwach bloku sowieckiego po 1956. Warszawa: Instytut Pamięci Narodowej.

Gnauck, G. (1999). Katz und Maus mit der Stasi. Miroslaw Chojecki, der größte Untergrundverleger des Ostblocks, erinnert sich an die polnische Erstausgabe der „Blechtrommel”. Die Welt, 4 Dezember. 
Grupiński, R. (1987). Nędza literatury. Czas Kultury, 3, 24-55.

Kandziora, J. i Szymańska, Z. (1999). Bez cenzury: 1976-1989: literatura, ruch wydawniczy, teatr. Warszawa: Instytut Badań Literackich.

Karpiński, J. (1988). Polska - komunizm - opozycja. Stownik. Warszawa: Wydawnictwo CDN.

Kopciński, J. (2015). Przesztość to dziś. Podręcznik dla klasy III liceum i technikum (wyd. wieloletnie). Warszawa: STENTOR.

Kosyra-Cieślak, T. (2015). Plan realizacji materiatu języka polskiego $w$ klasie III LO (plan wynikowy dwustopniowy). Warszawa: STENTOR. Pozyskano z: https://www.stentor.pl/files/produkty/pliki/przeszlosc_plan_ wynikowy_3.doc (dostęp: 01.04.2020).

Mielczarek, A. (2006). Śpiacy rycerze. Warszawa: Stowarzyszenie Wolnego Słowa.

Międzyrzecki, A. (1995). Minimum powagi i płaszcz Konrada. Gazeta Wybor$c z a, 89,13$.

Misiakiewicz, E. (2007). Czy literatura rzeczywiście „źle obecna w szkole”? Z doświadczeń praktyka. Zeszyty Szkolne, 1(23), 17-24.

Nadolna-Tłuczykont, M. (2013). Powrót ksiażek „zakazanych” do wspótczesnych odbiorców (wybrane zagadnienia). Katowice: Wydawnictwo Uniwersytetu Śląskiego.

Okładka Do Rzeczy, nr 29/128 z 13-19.07.2015.

Olaszek, J. (2015). Rewolucja powielaczy. Niezalezny ruch wydawniczy w Polsce 1976-1989. Warszawa: Trzecia Strona.

Olszewska, B., Surdyk-Fertsch, W. i Wojciechowski, G. (2020). Wczoraj i dziś. Podręcznik do historii dla klasy czwartej szkoty podstawowej. Warszawa: Nowa Era.

Pawet Piekarczyk - Drugi obieg $w$ kondominium (2012). Pozyskano z: https:// bliskopolski.pl/muzyka/pawel-piekarczyk-drugi-obieg-w-kondominium/ (dostęp: 05.04.2020).

Rozmowa z Henrykiem Grynbergiem. (1987). Czas Kultury, 3, 90-111.

SIL. (2011). Joanna Lichocka: po Smoleńsku powstat drugi obieg medialny. Dwie różne Polski, dwa obiegi, dwa kanaty kolportażu. Pozyskano z: https://wpolityce.pl/polityka/112049-joanna-lichocka-po-smolensku-powstal-drugi-obieg-medialny-dwie-rozne-polski-dwa-obiegi-dwa-kanaly-kolportazu (dostęp: 05.04.2020).

Szaruga, L. [wł. Wirpsza Aleksander] (1986a). Wielkie oczekiwanie. Kultura (Paryż), 5/464, 28-42.

Szaruga, L. [wł. Wirpsza Aleksander]. (1986b). Kochana prawico. Kultura (Paryż), 3/462, 139-143.

Śpiewak, P. (2005). Pamięć po komunizmie. Gdańsk: słowo/obraz terytoria.

Trznadel, J. (1990). Hańba domowa. Rozmowy z pisarzami. Lublin: Wydawnictwo Test. 
Krzysztof Okoński - germanista, profesor uczelni w Katedrze Komparatystyki Kulturowej (Instytut Nauk o Kulturze) na Uniwersytecie Kazimierza Wielkiego w Bydgoszczy. Zainteresowania badawcze: literatura i kultura niemiecka poza cenzurą w PRL i NRD, polsko-niemieckie kontakty kulturalne w kraju i na emigracji przed rokiem 1989, kultura i literatura niemiecko-turecka. Autor m.in. monografii Auf der Suche nach der verlorenen Freiheit (W poszukiwaniu utraconej wolności, Drezno 2017) o obrazie powojennych Niemiec i ich literatury w „Kulturze” paryskiej. 